\title{
Hubungan Antara Status Sosial Ekonomi Orang Tua dan Efikasi Diri dengan Minat Menjadi Guru Mahasiswa Program Studi Pendidikan Teknik Elektro Universitas Negeri Jakarta \\ ${ }^{1}$ Nur Hidayanti, ${ }^{2}$ Suyitno, ${ }^{3}$ Parjiman. \\ ${ }^{1,2,3}$ Pendidikan Teknik Elektro, Fakultas Teknik, Universitas Negeri Jakarta \\ 1,2,3Email: nhidayanti89@gmail.com ; suyitno@unj.ac.id ; parjiman@unj.ac.id
}

\begin{abstract}
The purpose of this study is to discover the level of strength: (1) relationship between parents's sosio-economic status with interest to become a teacher (2) relationship between self-efficacy with interest to become a teacher (3) relationship between parents's sosio-economic status with self-efficacy (4) relationship between parents's sosio-economic status and self-efficacy with interest to become a teacher with a of population 90 people and using a sample of 72 people, namely students of educational elekctrical engineering study program in State University of Jakarta. This study uses a quantitative method with analysis prerequisite test using normality test and linearity test, then the data is analyse by hypothesis testing, t-test and F-test with the significance level of 5\%. Based on the result hypothetical test calculation can be concluded: (1) There is a positive and significant relationship between parents's sosio-economic status with interest to become a teacherseen from the value of $r_{\text {count }}=0,551>r_{\text {table }}=0,232$ and $t_{\text {count }}=5,528>t_{\text {table }}=1,994$. In line with several studies that have been explained in section 4.4 of the results and discussion, that these studies also illustrate the existence of a relationship between parents's sosio-economic status with interest to become a teacher. (2) there is a positive and significant relationship relationship between self-efficacy with interest to become a teacher seen from the value of $r_{\text {count }}=0,682>r_{\text {table }}=0,232$ and $t_{\text {coun }} t=7,796>t_{\text {table }}=1,994$. In line with several studies that have been explained in section 4.4 of the results and discussion, that these studies also illustrate the self-efficacy with interest to become a teacher. (3) There is a positive and significant relationship between parents's sosioeconomic with self-efficacy seen from the value of $r_{\text {count }}=0,528>r_{\text {table }}=0,232$ and the value of $t_{\text {count }}=5,19512$ $>t_{\text {table }}=1,994$. (4) There is a positive and significant relationship between parents's sosio-economic status and self-efficacy with interest to become a teacherseen from the value of $r_{\text {count }}=0,718>r_{\text {table }}=0,232$ and $F_{\text {count }}=$ $36,7364>F_{\text {table }}=3,13$. In line with several studies that have been explained in section 4.4 of the results and discussion, that these studies also illustrate the existence of a relationship between parents's sosio-economic status and self-efficacy with interest to become a teacher.
\end{abstract}

Keyword: parent's socio-economic status, self-efficacy, interest to become a teacher

\begin{abstract}
ABSTRAK
Tujuan dari penelitian ini adalah untuk mengetahui tingkat keeratan hubungan (1) hubungan antara status sosial ekonomi orang tua dengan minat menjadi guru, (2) hubungan antara efikasi diri dengan minat menjadi guru, (3) hubungan antara status sosial ekonomi orang tua dengan efikasi diri, (4) hubungan antara status sosial ekonomi orang tua dan efikasi diri dengan minat menjadi guru dengan populasi sebanyak 90 orang dan jumlah sampel 72 orang.Penelitian ini menggunakan metode kuantitatif dengan uji prasyarat analisis menggunakan uji normalitas dan uji linieritas kemudian data dianalisis menggunakan uji hipotesis, uji-t dan uji-F dengan taraf signifikansi 5\%. Berdasarkan hasil perhitungan uji hipotesis dapat disimpulkan: (1) Terdapat hubungan yang positif dan signifikan antara status sosial ekonomi orang tua dengan minat menjadi guru dilihat dari nilai $\mathrm{r}_{\text {hitung }}=0,551>$ $r_{\text {tabel }}=0,232$ dan nilai $t_{\text {hitung }}=5,528 .>t_{\text {tabel }}=1,994$. Sejalan dengan beberapa penelitian yang telah dijelaskan pada sub bab 4.4 tentang hasil dan pembahasan, bahwa penelitian-penelitian tersebut juga menggambarkan terdapatnya hubungan antara status sosial ekonomi orang tua dengan minat menjadi guru. (2) Terdapat hubungan yang positif dan signifikan antara efikasi diri dengan minat menjadi guru dilihat dari dari nilai $\mathrm{r}_{\text {hitung }}=$ $0,682>\mathrm{r}_{\text {tabel }}=0,232 \mathrm{dan}$ nilai $\mathrm{t}_{\text {hitung }}=7,796>\mathrm{t}_{\text {tabel }}=1,994$. Sejalan dengan beberapa penelitian yang telah dijelaskan pada sub bab 4.4 tentang hasil dan pembahasan, bahwa penelitian-penelitian tersebut juga menggambarkan terdapatnya hubungan antara efikasi diri dengan minat menjadi guru. (3) Terdapat hubungan yang positif dan signifikan antara status sosial ekonomi orang tua dengan minat menjadi guru dilihat dari nilai $r_{\text {hitung }}=0,534>r_{\text {tabel }}=0,232$ dan nilai $F_{\text {hitung }}=5,195 \Rightarrow F_{\text {tabel }}=1,994$. (4) Terdapat hubungan yang positif dan signifikan antara status sosial ekonomi orang tua dan efikasi diri dengan minat menjadi guru guru dilihat dari dari nilai $\mathrm{r}_{\text {hitung }}=0,718>\mathrm{r}_{\text {tabel }}=0,232$ dan nilai $\mathrm{F}_{\text {hitung }}=36,7364>\mathrm{F}_{\text {tabel }}=3,13$. Sejalan dengan beberapa penelitian yang telah dijelaskan pada sub bab 4.4 tentang hasil dan pembahasan, bahwa penelitian-penelitian tersebut juga menggambarkan terdapatnya hubungan antara efikasi diri dengan minat menjadi guru.
\end{abstract}

Kata kunci: Status Sosial Ekonomi Orang Tua, Efikasi Diri,Minat Menjadi Guru 


\section{PENDAHULUAN}

Pendidikan memegang peranan penting bagi kelangsungan kehidupan manusia. Berawal dari kesuksesan di bidang pendidikanlah suatu bangsa menjadi maju. Melalui pendidikan, sumber daya manusia yang berkualitas sehingga menjadi motor penggerak kemajuan dan kemakmuran bangsa. ${ }^{[1]}$ Proses pendidikan terarah pada peningkatan penguasaan pengetahuan, kemampuan ketrampilan, pengembangan sikap dan nilai-nilai dalam rangka pembentukan dan pengembangan diri peserta didik (Sukmadinata, 2003:4). Tujuan pendidikan tidak hanya untuk mengembangkan pengetahuan anak, tetapi juga sikap kepribadian, serta aspek sosial emosional di samping ketrampilan-ketrampilan lain. ${ }^{[2]}$ Namun pada kenyataannya, menurut data UNESCO dalam Global Education Monitoring (GEM) Report, penddidikan Indonesia menempati urutan ke-10 dari 14 negara berkembang. Jumlah guru mengalami peningkatan sebanyak $38 \%$ menjadi sebanyak 3 juta lebih, sedangkan peningkatan jumlah peserta didik hanya $17 \%$. Dari 3,9 juta guru yang ada masih terdapat $25 \%$ guru yang belum memenuhi syarat kualifikasi akademik dan 52\% diantara belum memiliki sertifikat profesi. Dengan jumlah guru yang banyak, diharapkan kegiatan belajar yang optimal dapat tercapai. Sayangnya, meningkatnya kuantitas guru tidak sebanding dengan kualitasnya. Selain kualitas guru yang belum optimal kebutuhan serta jumlah guru di Indonesia juga masih terbilang belum merata dan belum mampu menjangkau seluruh sekolah di Indonesia. Pada saat ini masih Indonesia sangat kekurangan guru produktif di bidang SMK khususnya dalam bidang teknologi seperti jurusan Teknik Instalasi Tenaga Listrik. Namun kenyataanya pada saat ini banyak mahasiswa Universitas Negeri Jakarta khususnya Program Studi Pendidikan Teknik Elektro angkatan 2015 yang kurang memiliki minat dalam memilih profesi sebagai guru dan hal itu menjadi masalah bagi lembaga karna tidak sesuai dengan misi ada. Slameto mengemukakan, bahwa minat adalah suatu rasa lebih suka dan rasa keterikatan pada suatu hal atau aktivitas, tanpa ada yang menyuruh. Minat berperan dalam mendorong seseorang untuk mencapai tujuannya sehingga mahasiswa yang memiliki minat tinggi ia akan lebih cenderung memilih untuk melanjutkan pendidikan ke perguruan tinggi agar dapat mencapai cita-cita yang diingikannya. Begitu pula minat menjadi guru, profesi guru adalah profesi yang sangat mulia. Guru sangat dibutuhkan dalam dunia pendidikan untuk meningkatkan sumber daya manusia menjadi manusia yang lebih berkualitas dan dapat membangun bangsa menjadi bangsa yang lebih maju.

Ada beberapa faktor yang mempengaruhi minat, ${ }^{[3]}$ menurut Slameto (2013: 54) faktorfaktor yang mempengaruhi minat diantaranya adalah faktor internal dan faktor eksternal. Faktor-faktor eksternal meliputi faktor keluarga, faktor masyarakat, dan faktor sekolah. Salah satu faktor keluarga yang mempengaruhi minat ialah ststus sosial ekonomi orang tua, keaadan status sosial ekonomi orang tua merupakan salah satu faktor eksternal yang sangat berpengaruh besar terhadap minat seseorang, karena keluarga merupakan lingkungan sosial yang pertama kali dikenalkan kepada anak sehingga dengan begitu di dalam kehidupan masyarakat kita dapat menjumpai berbagai macam sifat dan karakter seorang anak karena hal tersebut berdasarkan situasi keluarga dan pengalamanpengalaman yang dimiliki oleh orang tuanya. Selain faktor status sosial ekonomi orang tua lalu ada faktor lain yang menimbulkan minat menjadi guru berasal dari faktor internal. Faktor-faktor tersebut meliputi faktor psikologi, faktor biologis, dan faktor kelelahan. Salah satu faktor psikologi yang mempengaruhi minat ialah efikasi diri. ${ }^{[4]}$ Menurut Bandura dalam Ghufron dan Risnawita (2014:73) self Efficacy atau efikasi diri adalah keyakinan individu mengenai mengenai kemampuan dirinya dalam melakukan tugas atau tindakan yang diperlukan untuk mencapai hasil tertentu. Efikasi dirimenentukan bagaimana orang-orang merasakan, berfikir, memotivasi dirinya dan berprilaku. Apabila seseorang memiliki efikasi diri yang tinggi, maka orang tersebut akan menetapkan target yang tinggi untuk apa yang diinginkan, menggunakan perasaan, mengarahkan motivasi dan perbuatan untuk 
dapat mencapai tujuan dan target yang diinginkan. ${ }^{[5]}$ Efikasi diri dalam hal ini adalah minat menjadi guru, guru yang memiliki efikasi diri yang tinggi dapat mempengaruhi kualitas pembelajaran yang dialami siswa (Hurlock, 2010). Efikasi diri seorang guru juga dapat mempengarahi kreativitas dan inovasi dalam kegiatan belajar dan mengajar.

Dari pernyataan di atas dapat disimpulkan bahwa minat mahasiswa untuk melanjutkan studi dengan katagori cukup, hal ini diduga karena efikasi diri yang dimiliki mahasiswa belum maksimal. Efikasi diri atau keyakinan yang rendah akan mempengaruhi kemampuan sesorang itu sendiri sehingga ini akan berpengaruh kepada cara mereka bereaksi terhadap masalah yang mereka hadapi yaitu berupa minat menjadi guru. Faktor lainnya yang mempengaruhi minat menjadi guru ialah sosial ekonomi orang tua yang rendah karena pada saat ini kondisi ekonomi masyarakat Indonesia masih dalam taraf menengah kebawah. Dalam rumusan masalah yang disampaikan diatas maka dari itu penulis akan membuat sebuah penelitian dengan judul "Hubungan antara Status Sosial Ekonomi Orang Tua dan Efikasi Diri dengan Minat Menjadi Guru Pada Mahasiswa Program Studi Pendidikan Teknik Elektro Universitas Negeri Jakarta".

\section{METODOLOGI PENELETIAN}

Jenis desain penelitian ini termasuk dalam penelitian deskriptif korelatif. ${ }^{[6]}$ Menurut Arikunto (2010: 3) penelitian yang dilakukan untuk mengetahui tingkat hubungan antara dua variabel atau lebih, tanpa melakukan perubahan, tambahan atau manipulasi terhadap data yang sudah ada. ${ }^{[7]}$ Penelitian ini menggunakan pendekatan kuantitatif, yaitu dengan pengumpulan data menggunakan instrumen penelitian, analisis data bersifat kuantitatif/statistik dengan tujuan untuk menguji hipotesis yang telah ditetapkan (Sugiyono, 2011: 14). Penelitian ini ditujukan untuk menguji hipotesis yang telah diajukan dengan cara mencari besarnya hubungan variabel bebas terhadap variabel terikat. Paradigma atau model hubungan antara variabel $\mathrm{X}_{1}$ dan $\mathrm{X}_{2}$ dan $\mathrm{Y}$ dapat digambarkan
$\mathrm{X}_{1}$ : Status Sosial Ekonomi Orang Tua (variabel bebas)

$\mathrm{X}_{2}$ : Efikasi Diri (variabel bebas)

Y: Minat Melanjutkan Menjadi Guru Mahasiswa Program Studi Pendidikan Teknik Elektro Universitas Negeri Jakarta (variabel terikat)

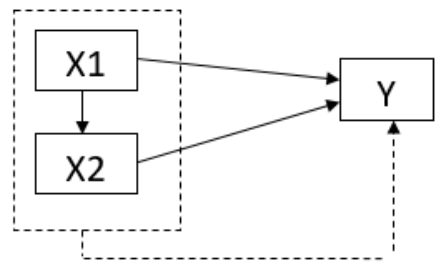

Gambar 3.1 Hubungan Antar Variabel

${ }^{[8]}$ Populasi merupakan wilayah generalisasi yang terdiri atas objek/ subjek yang mempunyai kualitas dan karakteristik tertentu yang ditetapkan oleh peneliti untuk dipelajari dan kemudian ditarik kesimpulannya (Sugiyono, 2010: 117). Populasi dalam penelitian ini adalah mahasiswa Program Studi Teknik Elektro angkatan 2015 sebanyak 90 mahasiswa dengan menggunakan sampel Issac dan Michael dengan menggunakan taraf 5\% dengan jumlah sampel sebanyak 72 mahasiswa. Teknik pengumpulan data untuk variabel status sosial ekonomi orang tua, efikasi diri, dan minat menjadi guru menggunakan kuesioner (angket). Instrumen penelitian diuji validitasnya menggunakan rumus rumus korelasi Pearson's Product Moment. Pengujian reliablitas pada instrumen kuesioner (angket) menggunakan koefisien reliabilitas Alfa Cronbach. Teknik analisis data yang digunakan dalam penelitian ini adalah statistik deskriptif.. Pengujian hipotesis dalam penelitian ini menggunakan nilai $\alpha=0,05$, namun sebelum melakukan uji hipotesis, terlebih dahulu dilakukan uji normalitas menggunakan Chi Kuadrat dan linearitas. Lalu setelah melakukan uji normalitas dan uji lilearitas maka dilakukan uji hipotesis menggunakan analisis korelasi Pearson's Product Moment., Uji t, dan uji F.

\section{HASIL DAN PEMBAHASAN Minat Menjadi Guru}

Berikut adalah distribusi frekuensi nilai minat menjadi guru yang dapat dilihat pada Tabel 1

Tabel 1. Distribusi Frekuensi Data Minat Menjadi Guru 


\begin{tabular}{|c|c|c|c|}
\hline No & $\begin{array}{c}\text { Kelas } \\
\text { Interval }\end{array}$ & Tepi Kelas & $f$ \\
\hline 1. & $66-71$ & $65,5-72,5$ & 12 \\
\hline 2. & $72-77$ & $72,5-77,5$ & 17 \\
\hline 3. & $78-83$ & $77,5-83,5$ & 16 \\
\hline 4. & $84-89$ & $83,5-89,5$ & 11 \\
\hline 5. & $90-95$ & $89,5-95,5$ & 9 \\
\hline 6. & 96-101 & $95,5-101,5$ & 4 \\
\hline \multirow[t]{3}{*}{7.} & $102-107$ & $101,5-$ & \\
\hline & & 107,5 & 3 \\
\hline & \multicolumn{2}{|c|}{ Jumlah } & 72 \\
\hline
\end{tabular}

Berdasarkan tabel distribusi frekuensi 1. bisa diketahui bahwa variabel minat menjadi guru memiliki frekuensi tertinggi yaitu sebesar 72 - 77 dan memiliki frekuensi relatif sebesar $24 \%$ dari total sampel, sedangkan frekuensi terendah yang terletak pada interval kelas ke 7 (tujuh) yakni antara $102-107$ dan memiliki frekuensi relatif sebesar $4 \%$ dari total sampel. Kemudian hasil lainnya yaitu sebanyak 12 mahasiswa memiliki nilai rentang $66-71$ sebesar $17 \%$, lalu 16 mahasiswa yang memiliki nilai pada rentang $78-83$ sebesar $22 \%$, lalu 11 mahasiswa yang memiliki nilai pada rentang 84 - 89 sebesar 15\%, lalu 9 mahasiswa yang lain memiliki rentang 90 - 95 sebesar $13 \%$ dan 4 mahasiswa memiliki rentang nilai $102-107$ sebesar 6\%

\section{Status Sosial Ekonomi Orang Tua}

Berikut adalah distribusi frekuensi nilai stat yang dapat dilihat pada Tabel 2

Tabel 2. Distribusi Frekuensi Data Status Sosial Ekonomi Orang Tua

\begin{tabular}{cccc}
\hline No & $\begin{array}{c}\text { Kelas } \\
\text { Interval }\end{array}$ & Tepi Kelas & F \\
\hline 1. & $47-52$ & $47,5-52,5$ & 10 \\
2. & $53-58$ & $53,5-58,5$ & 15 \\
3. & $59-64$ & $59,5-64,5$ & 17 \\
4. & $65-70$ & $65,5-70,5$ & 18 \\
5. & $71-76$ & $70,5-76,5$ & 6 \\
6. & $77-82$ & $77,5-82,5$ & 4 \\
7. & $83-88$ & $83,5-88,5$ & 2 \\
\hline \multicolumn{4}{c}{ Jumlah } \\
\hline
\end{tabular}

Berdasarkan tabel distribusi frekuensi 2. bisa diketahui bahwa variabel status sosial ekonomi orang tua memiliki frekuensi tertinggi yaitu sebesar 65 - 70 yaitu sebanyak 18 mahasiswa dan memiliki frekuensi relatif sebesar $25 \%$ dari total sampel, sedangkan frekuensi terendah dengan yang terletak pada interval kelas ke 7 (tujuh) yakni antara 83 - 88yaitu sebanyak 2 mahasiwa dan memiliki frekuensi relatif sebesar 3\% dari total sampel. Kemudian hasil lainnya yaitu sebanyak 10 mahasiswa memiliki nilai rentang 47 - 52 sebesar $14 \%$, lalu 15 mahasiswa yang memiliki nilai pada rentang 53 - 58 sebesar 21\%, lalu 17 mahasiswa yang memiliki nilai pada rentang 59 - 64 sebesar 15\%, lalu 6 mahasiswa yang lain memiliki rentang $71-76$ sebesar $8 \%$, dan 4 mahasiswa memiliki rentang nilai $77-82$ sebesar $6 \%$. Kesimpulan dari data tabel 4.5 dapat dilihat pada histogram pada gambar 2 .

\section{Efikasi Diri}

Berikut adalah distribusi frekuensi nefikasi diri yang dapat dilihat pada Tabel 3 dan Gambar 3.

Tabel 3. Distribusi Frekuensi Data Efikasi Diri

\begin{tabular}{lccc}
\hline No & $\begin{array}{c}\text { Kelas } \\
\text { Interval }\end{array}$ & Tepi Kelas & $\mathrm{F}$ \\
\hline 1. & $56-60$ & $55,560,5$ & 12 \\
2. & $61-65$ & $60,5-66,5$ & 17 \\
3. & $66-70$ & $66,5-70,5$ & 16 \\
4. & $71-75$ & $71,5-75,5$ & 11 \\
5. & $76-80$ & $76,5-80,5$ & 9 \\
6. & $81-85$ & $91,5-85,5$ & 4 \\
7. & $86-90$ & $86,5-90,5$ & 3 \\
\hline \multicolumn{4}{c}{ Jumlah } \\
\hline
\end{tabular}

Berdasarkan gambar 4.3 terlihat bahwa frekuensi tertinggi pada kelas ke empat yaitu pada pada interval 71 - 75 dengan jumlah frekuensi sebanyak 17 mahasiswa dengan nilai tengah 73 sebesar 24\%. Hal ini menunjukan bahwa sebagian besar efikasi diri mahasiswa terjadi pada rentang tersebut. Sedangkan frekuensi terendah berada pada kelas ke tujuh yaitu pada pada interval 86 - 90 dengan jumlah frekuensi sebanyak 5 mahasiswa dengan nilai tengah 92 dan memiliki presentase sebesar 7\% dari total sampel. Berdasarkan gambar 4.3 dapat dilihat bahwa kurva distribusi frekuensi efikasi diri berbentuk simestris dengan responden tertinggi pada batas kelas 72-76 sebanyak 17 orang mahasiswa, hal tersebut dapat disimpukan bahwa efikasi diri mahasiswa Program Studi Pendidikan Teknik elektro UNJ dalam kategori normal.

\section{Uji Normalitas}

Berikut adalah perhitungan uji normalitas status sosial ekonomi orang tua,efikasi diri, dan 
minat menjadi guru yang dapat dilihat pada Tabel 4.

Tabel 4. Uji Normalitas Status Sosial Ekonomi Orang Tua, Efikasi Diri, dan Minat Menjadi Guru

\begin{tabular}{|c|c|c|c|c|}
\hline $\begin{array}{c}\text { Uji } \\
\text { Normalit } \\
\text { as }\end{array}$ & $\begin{array}{l}\text { D } \\
\text { k }\end{array}$ & $\begin{array}{c}\chi^{2} \\
\text { tabel }\end{array}$ & $\begin{array}{c}\chi^{2} \\
\text { hitung }\end{array}$ & Ket \\
\hline Status & \multirow{3}{*}{6} & & & \\
\hline Sosial & & 12,5 & 3,38 & Nor \\
\hline Ekonomi & & 9 & 7 & mal \\
\hline \multicolumn{5}{|l|}{ Orang Tua } \\
\hline $\begin{array}{c}\text { Efikasi } \\
\text { Diri }\end{array}$ & 6 & $\begin{array}{c}12,5 \\
9\end{array}$ & $\begin{array}{c}3,64 \\
3\end{array}$ & $\begin{array}{l}\text { Nor } \\
\text { mal }\end{array}$ \\
\hline Minat & & 12,5 & 5,04 & Nor \\
\hline $\begin{array}{l}\text { Menjadı } \\
\text { Guru }\end{array}$ & 6 & 9 & 1 & mal \\
\hline
\end{tabular}

Pada tabel 4.10. untuk variabel status sosial ekonomi orang tua $\chi^{2}$ hitung $=3,387$ sedangkan $\chi_{\text {tabel }}^{2}=12,59$, untuk $\alpha=0,05$ dan $\mathrm{dk}=6$. karena $\chi^{2}$ hitung $\leq \chi_{\text {tabel }}^{2}$ maka dapat disimpulkan bahwa penyebaran data pada variabel status sosial ekonomi orang tua berdistribusi normal. Pada tabel 4.10. untuk variabel efikasi diri $\chi^{2}$ hitung $=3,6433$, sedangkan $\leq \chi_{\text {tabel }}^{2}=12,59$, untuk $\alpha=0,05$ dan $\mathrm{dk}=6$. karena $\chi^{2}$ hitung $\leq$ $\chi_{\text {tabel }}^{2}$ maka dapat disimpulkan bahwa penyebaran data pada variabel efikasi diri berdistribusi normal. Pada tabel 4.10. untuk variabel minat menjadi guru. $\chi^{2}$ hitung $=5,041$ sedangkan $\chi_{\text {tabel }}^{2}=12,59$, untuk $\alpha=0,05$ dan $\mathrm{dk}$ $=6$. karena $\chi^{2}$ hitung $\leq \chi_{\text {tabel maka dapat }}^{2}$ disimpulkan bahwa penyebaran data pada variabel status sosial ekonomi orang tua berdistribusi normal.

\section{Uji Linieritas}

Berikut adalah perhitungan uji linieritas status sosial ekonomi orang tua dengan minat menjadi guru yang dapat dilihat pada Tabel 5 .

Tabel 5. Uji Linieritas Status Sosial Ekonomi Orang Tua dengan Minat Menjadi

\begin{tabular}{cccccc}
\multicolumn{6}{c}{ Guru } \\
\hline $\begin{array}{c}\text { Uji } \\
\text { Linierita } \\
\mathbf{s}\end{array}$ & $\mathbf{n}$ & $\begin{array}{c}\mathbf{D} \\
\mathbf{k}\end{array}$ & $\begin{array}{c}\mathbf{F} \\
\text { hitung }\end{array}$ & $\begin{array}{c}\mathbf{F} \\
\text { tabel }\end{array}$ & Ket \\
\hline $\begin{array}{c}\text { Status } \\
\text { Sosial }\end{array}$ & & & & & \\
$\begin{array}{c}\text { Ekonomi } \\
\text { Orang } \\
\text { tua }\end{array}$ & 2 & 30 & 1,6 & $\begin{array}{c}1,7 \\
4\end{array}$ & $\begin{array}{c}\text { Linie } \\
\mathrm{r}\end{array}$ \\
\hline
\end{tabular}

\begin{tabular}{l}
\hline dengan \\
Menjadi \\
Guru \\
\hline
\end{tabular}

Berdasarkan hasil analisis varians (Anava) pada tabel 5 diketahui nilai variabel status sosial ekonomi orang tua dan minat menjadi guru yaitu $F_{\text {hitung }}=1,601$ dengan derajat kebebasan (dk) pembilang sebesar 30 dan $\mathrm{dk}$ penyebut sebesar 40 dan taraf signifikansi $\alpha=$ $5 \%$, maka diperoleh $F_{\text {tabel }}=1,74$. Dilihat dari kriteria pengujian yang digunakan, maka diperoleh hasil pengujian hipotesis tersebut menunjukkan $\mathrm{F}_{\text {hitung }}<\mathrm{F}_{\text {tabel }}$ maka $\mathrm{H}_{0}$ diterima yang berarti terdapat persamaan linier antara variabel status sosial ekonomi orang tua dengan variabel minat menjadi guru.

Selanjutnya adalah perhitungan uji linieritas status efikasi diri dengan minat menjadi guru yang dapat dilihat pada Tabel 6 .

Tabel 6. Uji Linieritas Efikasi Diri dengan Minat Menjadi Guru

\begin{tabular}{cccccc}
\hline $\begin{array}{c}\text { Uji } \\
\text { Linierita } \\
\text { s }\end{array}$ & n & Dk & $\begin{array}{c}\text { F } \\
\text { hitung }\end{array}$ & $\begin{array}{c}\text { F } \\
\text { tabel }\end{array}$ & Ket \\
\hline Efikasi & & & & & \\
Diri & 7 & & 1,08 & 1,7 & Lin \\
dengan & 2 & 29 & 6 & 4 & ier \\
$\begin{array}{c}\text { Menjadi } \\
\text { Guru }\end{array}$ & & & & & \\
\hline
\end{tabular}

Berdasarkan hasil analisis varians (Anava) pada tabel 4.12 diketahui nilai variabel efikasi diri dan minat menjadi guru yaitu $F_{\text {hitung }}=1,086$ dengan derajat kebebasan ( $\mathrm{dk}$ ) pembilang sebesar 29 dan dk penyebut sebesar 41 dan taraf signifikansi $\alpha=5 \%$, maka diperoleh $\mathrm{F}_{\text {tabel }}$ $=1,74$. Dilihat dari kriteria pengujian yang digunakan, maka diperoleh hasil pengujian hipotesis tersebut menunjukkan $\mathrm{F}_{\text {hitung }}<\mathrm{F}_{\text {tabel }}$ maka $\mathrm{H}_{0}$ diterima yang berarti terdapat persamaan linier antara variabel efikasi diri dengan variabel minat menjadi guru

\section{Uji Hipotesis}

\section{Hubungan antara Status Sosial Ekonomi Orang Tua dengan Minat Menjadi Guru}

Berikut adalah perhitungan uji Hipotesis korelasi pearson product moment status sosial ekonomi orang tua dengan minat menjadi guru dapat dilihat pada Tabel 7. dan Tabel 8 untuk Uji Signifikansi Korelasi. 
Tabel 7. Uji Korelasi Pearson Product Moment

\begin{tabular}{ccccc}
\hline $\mathbf{d k}$ & $\mathbf{a}$ & $\begin{array}{c}\mathbf{r} \\
\text { hitung }\end{array}$ & $\begin{array}{c}\mathbf{r} \\
\text { tabel }\end{array}$ & Ket \\
\hline 72 & 0,05 & 0,551 & 0,232 & $\begin{array}{c}\mathrm{Ha} \\
\text { Diterima }\end{array}$ \\
\hline
\end{tabular}

Tabel 8. Uji Signifikansi Korelasi (Uji t)

\begin{tabular}{ccccc}
\hline dk & a & $\begin{array}{c}\mathbf{t} \\
\text { hitung }\end{array}$ & $\begin{array}{c}\mathbf{t} \\
\text { tabel }\end{array}$ & Ket \\
\hline 72 & 0,05 & 5,52871 & 1,994 & $\begin{array}{c}\text { Ha } \\
\text { Diterima }\end{array}$ \\
\hline
\end{tabular}

\section{Hubungan antara Efikasi Diri dengan Minat Menjadi Guru}

Berikut adalah perhitungan uji Hipotesis korelasi pearson product moment status efikasi diri dengan minat menjadi guru dapat dilihat pada Tabel 9 dan Tabel 10 untuk Uji Signifikansi Korelasi.

Tabel 9. Uji Korelasi Pearson Product Moment

\begin{tabular}{ccccc}
\hline dk & $\mathbf{a}$ & $\begin{array}{c}\mathbf{r} \\
\text { hitung }\end{array}$ & $\begin{array}{c}\mathbf{r} \\
\text { tabel }\end{array}$ & Ket \\
\hline 72 & 0,05 & 0,682 & 0,232 & $\begin{array}{c}\mathrm{Ha} \\
\text { Diterima }\end{array}$ \\
\hline
\end{tabular}

Tabel 10. Uji Signifikansi Korelasi (Uji t)

\begin{tabular}{ccccc}
\hline dk & $\mathbf{a}$ & $\begin{array}{c}\mathbf{t} \\
\text { hitung }\end{array}$ & $\begin{array}{c}\mathbf{t} \\
\text { tabel }\end{array}$ & Ket \\
\hline 72 & 0,05 & 7,79688 & 1,994 & $\begin{array}{c}\mathrm{Ha} \\
\text { Diterima }\end{array}$ \\
\hline
\end{tabular}

\section{Hubungan antara Status Sosial Ekonomi Orang Tua dengan Efikasi Diri}

Selanjutnya adalah perhitungan uji Hipotesis korelasi pearson product moment status status sosial ekonomi orang tua dengan efikasi diri dapat dilihat pada Tabel 11 dan Tabel 12 untuk Uji Signifikansi Korelasi.

Tabel 11. Uji Korelasi Pearson Product Moment

\begin{tabular}{ccccc}
\hline \multicolumn{5}{c}{ Moment } \\
dk & a & $\begin{array}{c}\mathbf{r} \\
\text { hitung }\end{array}$ & $\begin{array}{c}\mathbf{r} \\
\text { tabel }\end{array}$ & Ket \\
\hline 72 & 0,05 & 0,528 & 0,232 & $\begin{array}{c}\text { Ha } \\
\text { Diterima }\end{array}$ \\
\hline
\end{tabular}

Tabel 12. Uji Signifikansi Korelasi (Uji t)

\begin{tabular}{ccccc}
\hline dk & $\mathbf{a}$ & $\begin{array}{c}\mathbf{t} \\
\text { hitung }\end{array}$ & $\begin{array}{c}\mathbf{t} \\
\text { tabel }\end{array}$ & Ket \\
\hline 72 & 0,05 & 5,28523 & 1,994 & $\begin{array}{c}\text { Ha } \\
\text { Diterima }\end{array}$ \\
\hline
\end{tabular}

Selanjutnya adalah perhitungan uji Hipotesis korelasi pearson product moment status sosial ekonomi orang tua dan efikasi diri dengan minat menjadi guru dapat dilihat pada Tabel 13 dan Tabel 14 untuk Uji Signifikansi Korelasi.

Tabel 13. Uji Korelasi Pearson Product Moment

\begin{tabular}{ccccc}
\hline dk & $\mathbf{a}$ & $\begin{array}{c}\mathbf{r} \\
\text { hitung }\end{array}$ & $\begin{array}{c}\mathbf{r} \\
\text { tabel }\end{array}$ & Ket \\
\hline 72 & 0,05 & 0,718 & 0,232 & $\begin{array}{c}\text { Ha } \\
\text { Diterima }\end{array}$ \\
\hline
\end{tabular}

Tabel 14. Uji Signifikansi Korelasi (Uji F)

\begin{tabular}{ccccc}
\hline dk & a & $\begin{array}{c}\mathbf{F} \\
\text { hitung }\end{array}$ & $\begin{array}{c}\mathbf{F} \\
\text { tabel }\end{array}$ & Ket \\
\hline 72 & 0,05 & 36,73684 & 3,13 & $\begin{array}{c}\text { Ha } \\
\text { Diterima }\end{array}$ \\
\hline
\end{tabular}

\section{KESIMPULAN DAN SARAN \\ Kesimpulan}

Berdasarkan hasil penelitian dan pengolahan data yang telah dilakukan disimpulkan bahwa terdapat hubungan positif dan signifikan antara status sosial ekonomi orang dengan minat menjadi guru. Hasil ini dibuktikan oleh perhitungan uji hipotesis yang mendapatkan hasil $\mathrm{r}_{\mathrm{yx} 1}=0,551$ dan $\mathrm{t}_{\text {hitung }}=$ 5,528. Hasil tersebut bisa dikatakan positif dan signifikan karena $r_{\text {hitung }} \geq r_{\text {tabel }}$, dengan ketentuan $r_{\text {tabel }}=0,232$ dan $t_{\text {hitung }}>t_{\text {tabel }}$ dengan ketentuan $\mathrm{t}_{\text {tabel }}=1,994$.

Selanjutnya berdasarkan hasil penelitian dan pengolahan data yang telah dilakukan disimpulkan bahwa terdapat hubungan positif dan signifikan antara efikasi diri dengan minat menjadi guru. Hasil ini dibuktikan oleh perhitungan uji hipotesis yang mendapatkan hasil $r_{\mathrm{yx} 2}=0,682$ dan $t_{\text {hitung }} 7,79688$. Hasil tersebut bisa dikatakan positif dan signifikan karena $r_{\text {hitung }} r_{\text {tabel }}$, dengan ketentuan $r_{\text {tabel }}=$ 0,232 dan $t_{\text {hitung }} \geq t_{\text {tabel }}$ dengan ketentuan $t_{\text {tabel }}$ 1,994 .

Berdasarkan hasil penelitian dan pengolahan data yang telah dilakukan disimpulkan bahwa terdapat hubungan positif dan signifikan antara status sosial ekonomi orang tua dengan efikasi diri. Hasil ini dibuktikan oleh perhitungan uji hipotesis yang mendapatkan hasil $\mathrm{r}_{\mathrm{yx} 1,2}=0,528$ dan $\mathrm{t}_{\text {hitung }}=$ 
5,19512. Hasil tersebut bisa dikatakan positif dan signifikan karena $r_{\text {hitung }}>r_{\text {tabel }}$, dengan ketentuan $r_{\text {tabel }}=0,232$, dan $t_{\text {hitung }}>t_{\text {tabel }}$ dengan ketentuan $\mathrm{t}_{\text {tabel }} 1,994$.

Berdasarkan hasil penelitian dan pengolahan data yang telah dilakukan disimpulkan bahwa terdapat hubungan positif dan signifikan antara status sosial ekonomi orang tua dan efikasi diri dengan minat menjadi guru. Hasil ini dibuktikan oleh perhitungan uji hipotesis yang mendapatkan hasil $r_{\mathrm{yx} 1,2}=0,718$ dan $F_{\text {hitung }}=36,73684$. Hasil tersebut bisa dikatakan positif dan signifikan karena $r_{\text {hitung }} \geq$ $r_{\text {tabel }}$, dengan ketentuan $r_{\text {tabel }}=0,232$ dan $F_{\text {hitung }}$ $\geq \mathrm{F}_{\text {tabel }}$ dengan ketentuan $\mathrm{F}_{\text {tabel }}=3,13$.

\section{Saran}

a. Bagi mahasiswa

Mahasiswa hendaknya meningkatkan persepsinya bahwa profesi guru pekerjaan yang bergengsi, karena profesi guru merupakan profesi yang mulia dapat menularkan ilmu pengetahuan orang lain dan dihargai oleh masyarakat. Selain itu, mahasiswa ada baiknya membantu meningkatkan keadaan status sosial ekonomi orang tua dengan cara belajar, bekerja, berusaha dan memiliki target untuk masa dapan yang lebih baik.

b. Bagi orang tua

Meskipun memiliki penghasilan yang rendah hendaknya tidak membatasi gerak anak untuk berprestasi dan memilih profesi sesuai kemampuannya, karena meskipun dengan keterbatasan biaya saat ini ada alternatif untuk mengikuti program Bidikmisi dan beasiswa lain yang dapat membantu biaya pendidikan.

c. Bagi dosen

Kategori keadaan status sosial dan ekonomi orang tua mahasiswa pendidikan teknik elektro 2015 termasuk dalam kategori sangat rendah, maka dari itu untuk kedepannya dosen hendaknya memberikan penguatan mengenai profesi guru yang tidak hanya mencari kesejahteraan hidup namun guru merupakan panggilan jiwa dari hati dan niat yang tulus untuk menjadi pendidik. Selain itu, Hendaknya dosen di lingkungan Prodi Pendidikan Teknik Elektro Universitas Negeri Jakarta merancang pembelajaran yang mampu menumbuhkan efikasi diri dalam diri mahasiswa, karena dengan terbangunnya efikasi diri akan meningkatkan minat yang akhirnya akan menjadi dorongan untuk menjadi guru.

d. Bagi penelitian selanjutnya

Sebagai bahan masukan dan pengetahuan untuk diteliti lagi variabel lain yang mempengaruhi minat menjadi guru. Ada beberapa variabel lain yang dapat mempengaruhi seperti dukungan keluarga, lingkungan teman bergaul, kesejahteraan guru, dan sebagainya. Selain itu, Mengganti konsep teori penelitian dengan yang lebih spesifik seperti, menggunakan teori-teori baru yang akan digunakan dalam penyusunan skala agar dapat lebih mengungkapkan keadaan subjek penelitian.

e. Bagi Prodi

Dalam proses penerimaan mahasiswa perlu memperhatikan aspek psikologis seperti efikasi diri agar mendapat input calon guru yang berkualitas. Selain itu perlu disediakan fasilitas belajar dan memperbanyak penerimaan mahasiswa khususnya dari keluarga miskin yang terkendala keterbatasan biaya studi di Universitas Negeri Jakarta.

\section{DAFTAR PUSTAKA}

[1] Sukmadinata, Nana Syaodih. 2003. Landasan Psikologi Proses Pendidikan. Bandung : Remaja Rosdakarya.

[2] Kemendikbud. 2016. Indonesia Tuan Rumah Peluncuran Laporan Pemantauan Pendidikan Global UNESCO2016:https://www.kemdikbud.go. $\mathrm{id} / \mathrm{main} / \mathrm{blog} / 2016 / 09 /$ indonesia-tuanrumah-peluncuran-laporan-pemantauanpendidikan-global-unesco-2016._Diakses 1 Agustus 2019 pukul 20.32 WIB

[3] Slameto. 2013. Belajar dan Faktor-faktor yang Mempengaruhinya. Jakarta:Bina Aksara.

[4] Ghufron, M Nur. 2012.Teori-teori Psikologi.Yogyakarta:AR-RUZZ MEDIA

[5] Hurlock, Elizabeth B. 2010. Psikologi perkembangan: Suatu Pendekatan Sepanjang Rentang. Kehidupan. Jakarta: Erlangga

[6] Arikunto, Suharsimi. 2010. Prosedur Penelitian Suatu Pendekatan Publik. Jakarta: Bumi Aksara 
[7] Sugiyono. 2011. Statistika Untik Penelitian. Bandung: Alfabeta

[8] Sugiyono. 2010. Metode Penelitian Kuantitatif Kualitatif dan $R$ \& D. Bandung: Alfabeta. 